\title{
ETNOTOPOGRAFIA NOWEGO SADU O DZIEDZICTWIE NARODÓW OSIEDLAJĄCYCH SIĘ W NOWYM SADZIE
}

\author{
TOMASZ KWOKA
}

\begin{abstract}
Ethnic topography of Novi Sad. The heritage of nations inhabiting the city.
The article is an attempt to catalogue the most interesting traces of the presence of nations which were part of the Novi Sad community throughout the ages. From the very beginning of its existence, Novi Sad was a meeting place for different ethnic and cultural groups settling down in the city. Serbs from the surrounding countryside moved to the oldest districts of Novi Sad, Podbara, Salajka, and Rotkvarija, at the beginning of the $18^{\text {th }}$ century. At the same period nations from different parts of the Habsburg Empire, such as Germans, Hungarians, Slovaks and Ruthenians brought by Habsburgs to colonize Vojvodina, moved to the city. It was the time of continuous development of Novi Sad, which became an important trading and manufacturing centre, where businesses were also run by the Jews, Armenians, Aromanians (Tzintzars), and the Greeks. The turn of the $19^{\text {th }}$ and $20^{\text {th }}$ centuries was marked by the strengthening of presence of the Hungarian community, which ended with the First World War. After the establishment of the Kingdom of Serbs, Croats and Slovenes (1918), the ethnic structure changed seriously with the influx of Serbs from the southern regions of the country. This trend was followed after the Second World War and most recently during the period of the so-called Yugoslav wars at the Nineties. In the meantime, under dramatic circumstances of the second World War, German and Jewish inhabitants vanished from the city.
\end{abstract}

STRESZCZENIE. Artykuł jest próbą inwentaryzacji najciekawszych śladów obecności grup narodowych, które tworzyły Nowy Sad na przestrzeni wieków. Miasto to od początków istnienia było miejscem, w którym osiedlało się i spotykało wiele kultur. Na początku XVIII wieku najstarsze dzielnice miasta, Podbara, Salajka, Rotkvarija, zostały zasiedlone przez Serbów z okolicznych wsi. W tym samym czasie w Wojwodinie postępowało osadnictwo z udziałem narodów z różnych regionów cesarstwa habsburskiego - Niemców, Węgrów, Słowaków, Rusinów. Miasto się rozwijało, stając się ważnym centrum rzemieślniczo-kupieckim, w którym swoje interesy prowadzili także Żydzi, Ormianie, Cincarzy i Grecy. Przełom XIX i XX wieku to wzmacnianie żywiołu węgierskiego, które zakończyła I wojna światowa. Z kolei po powstaniu Królestwa SHS (1918) nastąpił znaczący napływ Serbów z południowych regionów państwa. Trend ten był kontynuowany po II wojnie światowej i w czasie rozpadu socjalistycznej Jugosławii. Z kolei w następstwie dramatycznych okoliczności II wojny światowej, z miasta zniknęli jego żydowscy i niemieccy mieszkańcy.

Autor: Tomasz Kwoka, Uniwersytet Jagielloński, Instytut Filologii Słowiańskiej, ul. Romana Ingardena 3, 30-060 Kraków, Polska, email: tomakwoka@gmail.com

Keywords: Novi Sad, Vojvodina, Serbia, national minorities, colonisations, migrations

Słowa kluczowe: Nowy Sad, Wojwodina, Serbia, mniejszości narodowe, kolonizacje, migracje

Balcanica Posnaniensia. Acta et studia, XXIV, Poznań 2017, Wydawnictwo Instytutu Historii UAM, pp. 127142, ISBN 978-83-65663-50-4, ISSN 0239-4278. Polish text with summaries in English and Polish.

doi.org/10.14746/bp.2017.24.8 
Nowy Sad to stosunkowo młode, nieco ponad 300-letnie miasto stworzone przez przedstawicieli różnych narodowości i konfesji, którzy nad Dunaj przybyli ze wszystkich stron świata. Każda $z$ tych wspólnot w tkance miejskiej pozostawiła swój ślad, który ciągle można zobaczyć, choć niestety część z nich już jedynie oczami wyobraźni...

W niniejszym artykule chciałbym, na tle kolejnych fal osadniczych, zmian struktury etnicznej i ogólnego rozwoju miasta, przedstawić najciekawsze zabytki - ślady obecności wspólnot narodowych, które są świadectwem udanej wojwodińskiej wersji wielokulturowości.

\section{WOJWODINA}

Nowy Sad jest stolicą Wojwodiny, która po raz pierwszy jako region z pewną dozą autonomii powstała w burzliwych latach Wiosny Ludów, najpierw pod nazwą Srpska Vojvodina, a potem Vojvodstvo Srbija i Tamiški Banat w granicach imperium habsburskiego ${ }^{1}$. Nowożytna historia tego regionu, umiejscowionego na granicy Bałkanów i Europy Środkowej, rozpoczyna się jednak już pod koniec XVII wieku, po wojnie austriacko-tureckiej (1683-1699) oraz wyparciu Turków z Wojwodiny po podpisaniu pokoju karłowickiego (1699), a potem także pożarewackiego (1718).

Od końca XVII wieku na wyludnione i wojną spustoszone ziemie Niziny Panońskiej napływali Serbowie z terenów Starej Serbii i Kosowa, w latach 1690 i 17371739 pod przewodnictwem swoich patriarchów. Z tego samego kierunku przybyli także Cincarzy i Grecy ${ }^{2}$, Ormianie, albańscy Klimenti ${ }^{3}$. Z zachodu przywędrowali

\footnotetext{
${ }^{1} \mathrm{Na}$ tzw. Zgromadzeniu Majowym (1/13 i 3/15 maja 1848 roku) w Sremskich Karłowicach, Serbowie ogłosili powstanie autonomicznej prowincji Srpska Vojvodina, która jednak nie została uznana przez cesarza. Dopiero rok później, w „nagrodę” za walkę po stronie Austrii, powołano Vojvodstvo Srbija i Tamiški Banat, które istniały do 1860 roku. Wtedy cały ten obszar przeszedł spod władzy cesarza austriackiego pod bezpośrednią władzę węgierską. W okresie Królestwa SHS (1918-1929), od 1922 r., na terenie Wojwodiny znajdowały się obwody Baczki, Belgradu, Dunaju i Sremu. W Królestwie Jugosławii, dekretem królewskim z 3 października 1929 r., obszar Wojwodiny wszedł do Banowiny Dunajskiej. Po II wojnie światowej stworzony został, w istniejących do dziś granicach, autonomiczny region Wojwodina, w obrębie Socjalistycznej Republiki Serbii; D. Boarov, Politička istorija Vojvodine: $u$ trideset tri priloga, Novi Sad 2001.

${ }^{2}$ Wołoscy Cincarzy wymieniani są wspólnie z Grekami ponieważ, w wyniku hellenizacji i asymilacji tych pierwszych, trudno rozpoznać ich oryginalne pochodzenie etniczne. Według Jovana Popovicia, Cincarzy stanowili grupę zromanizowanych potomków Traków i Ilirów, którzy pierwotnie zamieszkiwali Epir, Tesalię i Macedonię. W XVII i XVIII wieku pojawili się w miastach bałkańskich, gdzie zajmowali się handlem; Љ. Церовић, Народи на тлу Војводине. Од праисторије до двадесетог века, Нови Сад 2015, s. 129-131.

${ }^{3}$ Klimenti - katoliccy Albańczycy, którzy w 1737 roku przybyli do Sremu z północnego Kosowa (wsie Nikinci i Hrtkovci). Jako katolicy, szybko ulegli asymilacji i obecnie ich potomkowie są uznawani za Chorwatów; ibidem, s. 151-152.
} 
Szokcy, Buniewcy i Chorwaci ${ }^{4}$, a ze wschodu Rumuni i katoliccy Bułgarzy - Palćeni ${ }^{5}$. Z północy przybyli Niemcy oraz Francuzi, Włosi, Katalończycy, także Czesi, Słowacy, Rusini, Węgrzy, Żydzi, Romowie. W późniejszych czasach w Wojwodinie osiedlali się także Ukraińcy, Słoweńcy, Macedończycy, Gorańcy ${ }^{6}$ inni.

\section{KOLONIZACJE}

Po wycofaniu się z Panonii imperium osmańskiego, dwór w Wiedniu ruszył do wielkiej akcji kolonizacji, której celem było zagospodarowanie wielkich obszarów ziemi uprawnej, zwiększenie wpływów z podatków, a także wzmocnienie strefy obronnej przez Turkami. Według profesora Slavka Gavrilovicia, dwór wiedeński želeo je da poveća obradive površine, razvije proizvodnju i trgovinu, privuče što višse plemenitih metala preko trgovine s Turskom, poveća broj poreskih obveznika i tako ojača svoje stalno nesigurne finansije ${ }^{7}$.

O kolonizacji jako działaniu zgodnym z ideami merkantylizmu pisał Gerhard Seewann w monografii poświęconej niemieckim migracjom:

Politika naseljavanja i impopulaciona politika 18. veka, koja je vođena u skladu sa merkantilističkim idejama, doprinela je u velikoj meri obnovi zemlje, porastu gustine naseljenosti i modernizaciji poljoprivrede, a naposletku, u značajnoj meri, promeni privredne strukture, u smislu privrednog razvoja do tada perifernih oblasti kraljevine. U stoleću naseljavanja postavljen je kamen temeljac moderne Mađarske, u kojoj se postepeno razvijalo građansko društvo ${ }^{8}$.

Najliczniejszą grupą habsburskich osadników byli Niemcy, których kilkaset tysięcy w ciągu XVIII i XIX wieku przesiedliło się do Europy wschodniej i południowowschodniej. Powodów do wyjazdów mieli sporo: niedostatek gruntów rolnych w miejscu dotychczasowego ich zamieszkana, bieda, niskie ceny zbóż oraz ciągłe wojny. $\mathrm{Z}$ drugiej zaś strony dwór wiedeński (i prywatni właściciele gruntów, wśród nich także dostojnicy kościelni) zapewniali zwolnienie z podatków oraz pomoc w podróży,

${ }^{4}$ Szokcy i Buniewcy (Šokci, Bunjevci) - chorwackie grupy etnograficzne, pojawiły się na terenie dzisiejszej Wojwodiny w XVI wieku. Przodkowie Szokców przesiedlili się z Dalmacji do środkowej Bośni, a stamtąd, w połowie XVI wieku, do Sremu i Baczki. Buniewcy pojawili się w Wojwodinie w XVII wieku. Najpierw opuścili pod naciskiem tureckiego terroru wschodnią Hercegowinę i Bośnię, przesiedlając się do Dalmacji, a następnie do Panonii. Obecnie Buniewcy są uznawani za mniejszość, a ich etnolekt i ich kultura są nauczane w szkołach. Zamieszkują oni północno-zachodnią część Wojwodiny, także miasta Sombor i Subotica; ibidem, s. 118-119.

${ }^{5}$ Palćeni to katolicka bułgarska grupa etnograficzna z północno-zachodniej Bułgarii, która w XVIII wieku osiedliła się w serbskim Banacie; ibidem, s. 149-151.

${ }^{6}$ Gorańcy (Goranie) to zislamizowana mniejszość słowiańska pochodząca z górskich terenów południowo-zachodniego Kosowa (region Gora, gmina Dragaš) i posługująca się językiem słowiańskim (serbskim).

${ }^{7}$ С. Гавриловић, Студије из привредне и друштвене историје Војводине и Славоније од краја XVII до средине XIX века, Нови Сад 2009, s. 10.

${ }^{8}$ G. Seewann, O istoriji „Švaba na Dunavu”, w: Migracije u Podunavlju. Kolonizacija Nemaca u 18. veku i njene posledice, Novi Sad 2013, s. 25. 
przy budowie domu i zakupie ziemi ${ }^{9}$. Kolonizacji towarzyszyły też wielkie inwestycje infrastrukturalne ułatwiające życie i sprzyjające rozwojowi ekonomicznemu: tworzenie wsi z charakterystycznym geometrycznym układem ulic i parceli, melioracja i osuszanie terenów podmokłych, regulacja rzek oraz budowa kanałów, dróg i mostów ${ }^{10}$.

Kolonizacja odbywała się na podstawie dokumentów cesarskich. Pojedynczy osadnicy pojawiali się już na przełomie XVII i XVIII w., ale I etap oficjalnej kolonizacji - tzw. karoliński (za panowania Karola VI), miał miejsce w latach 1722-1726 i objął od około dziesięciu po dwunastu tysięcy Niemców. W najlepiej zorganizowanym, II etapie, tzw. terezjańskim, na Węgry przybyło około 100 tysięcy osób. Etap III, tzw. józefiński, objął w sumie około 45 tysięcy osób. Zdecydowaną większość przybyłych stanowili katolicy, ponieważ dopiero po 1781 r., po cesarskim Patencie tolerancyjnym, zgodę na osiedlanie otrzymali również protestanci ${ }^{11}$.

Ważnym, ze względu na przybycie kolejnych grup etnicznych, wydarzeniem był rok 1739, kiedy to wraz z wycofującymi się z Serbii ${ }^{12}$ Austriakami, Belgrad opuścili i Wojwodinę zasiedlili Niemcy, Serbowie Macedończycy, Cincarzy, Grecy, Ormianie i Żydzi, głównie kupcy i rzemieślnicy. Dołączyli oni do tworzącej się elity miejskiej, która już dziesięć lat później wystąpiła o nadanie osadzie o nazwie Petrovaradinski Šanac statusu wolnego miasta ${ }^{13}$.

\section{NOWY SAD}

Początek Nowego Sadu ściśle związany jest z rozpoczęciem budowy austriackiej twierdzy Petrovaradin nad Dunajem w 1692 roku. Na przeciwległym do twierdzy brzegu, w 1694 roku zbudowano tzw. Mostobran (Brukšanac, Brück Schanze) ${ }^{14}$, wokół którego rozwinęła się osada Petrovaradinski Šanac, znana także jako Racka Varoš, a od 1748 roku oficjalnie nosząca nazwę Novi Sad. Serbscy budowniczowie oraz rzemieślnicy, którym nie wolno było osiedlać się przy samej twierdzy, mieszkali we wschodniej części przyszłego miasta, do połowy XVIII wieku podległej wojskowej administracji Pogranicza Wojskowego. Ich sąsiedzi - Niemcy, Żydzi i Węgrzy zajmowali zachodnią, cywilną część osady ${ }^{15}$.

\footnotetext{
${ }^{9}$ Ibidem, s. 20-21.

10 Ibidem, s. 74.

${ }^{11}$ Zavičaj na Dunavu. Suživot Nemaca i Srba u Vojvodini, red. V. Mitrović, Novi Sad-Ulm 2009, s. 95 .

${ }^{12} \mathrm{~W}$ latach 1718-1739 monarchia habsburska panowała na terenie dzisiejszej centralnej Serbii, w Belgradzie i regionach Šumadija, Mačva, Braničevo i Timočka Krajina.

13 Ibidem, s. 94.

${ }^{14}$ Był to ufortyfikowany przyczółek nad rzeką, służący obronie twierdzy i mostu pontonowego. Znajdująca się w miejscu dzisiejszego Mostu Varadinskiego, budowla została zburzona w latach 30 . XX wieku, w związku z rozwojem i rozbudową miasta w kierunku Dunaju.

${ }^{15}$ Według danych z 1715 r., spośród 37 rodzin w Petrovaradinskim Šancu, 15 miało pochodzenie niemieckie; ibidem, s. 162.
} 
W kolejnych dekadach XVIII wieku w Petrovaradinskim Šancu osiedlali się Serbowie, zarówno z dalszych jak i z najbliższych okolic (np. wsi Almaš) ${ }^{16}$, Szokcy i Buniewcy ze Sremu, a także coraz więcej Niemców, przedkładających tę osadę nad nieznane wsie Banatu i Baczki. Kolejne fale osadników przybywały z opuszczanego przez Austriaków Belgradu i Paszałyku Belgradzkiego w latach 1737-1739. Do końca XVIII wieku pojawili się jeszcze Żydzi, Słowacy, Rusini, Rumuni i inni, w tym także protestanci (po 1781).

Nowy Sad szybko zyskiwał coraz większe znaczenie. W 1702 roku przeniesiono tutaj z Segedynu siedzibę prawosławnego biskupstwa Baczki i już wkrótce miasto pochwalić się mogło 4 cerkwiami prawosławnymi i 2 kościołami katolickimi ${ }^{17}$. Dzięki korzystnemu położeniu geograficznemu oraz wielonarodowym mieszkańcom z międzynarodowymi kontaktami stawał się Nowy Sad silnym ośrodkiem kupiecko-rzemieślniczym. Aby uwolnić się spod krępującej węgierskiej władzy lokalnej, przede wszystkim serbscy i niemieccy mieszczanie, wśród nich także przybysze z Belgradu (Beligradci), zainicjowali starania o uzyskanie statusu wolnego królewskiego miasta. Moment był odpowiedni, kasa cesarstwa świeciła pustkami, więc za około 96 tysięcy guldenów ${ }^{18} 1$ lutego 1748 roku, cesarzowa Maria Teresa ogłosiła nadanie statusu Wolnego Królewskiego Miasta Neoplanta, Neu Satz i Uj Videgh ${ }^{19}$.

Nowy Sad uzyskał autonomię, uprzywilejowaną pozycję i wolność gospodarczą, a mieszkańcy zostali zwolnieni z części podatków. Okres do połowy XIX wieku to szybki rozwój, w którym ważną rolę odgrywała wieloetniczna elita miejska uformowana z grona rzemieślników (głównie Serbowie i Niemcy) i kupców (Serbowie, Grecy, Cincarzy i Ormianie handlujący ze wschodem, Niemcy - handlujący z zachodem). Miastem rządził dwunastoosobowy Magistrat, w połowie katolicki, w połowie prawosławny oraz burmistrz - Niemiec i szef policji - Serb.

Rozwój ekonomiczny w sposób naturalny powodował zwiększenie liczby mieszkańców i napływ ludności różnych narodowości: w 1698 w osadzie mieszkały zaledwie 32 rodziny, w 1748 roku - 4620 osób, a w 1828 roku już 20231 osób (62\% prawosławnych, 28\% katolików, 6\% protestantów i 4\% Żydów) ${ }^{20}$. Dynamiczny rozwój miasta spowodował, że w połowie XIX wieku Nowy Sad należał do dziesięciu najludniejszych miast Węgier, z procentowo dominującą grupą kupców i rzemieślników.

$16 \mathrm{~W} 1715$ roku w tej części miasta mieszkało dwadzieścia rodzin serbskich; Име и презиме: Нови Сад, Нови Сад 2010, s. 97.

17 Do najstarszych serbskich cerkwi w mieście zalicza się cerkiew katedralną św. Jerzego (Saborna crkva sv. Georgija), cerkiew św. Mikołaja (Nikolajevska crkva), nieistniejącą cerkiew św. Jana Chrzciciela (Svetojovanovska crkva) i cerkiew Trzech Hierarchów (Almaška crkva). Nieco nowsza jest cerkiew Zaśnięcia NMP (Uspenjska crkva). Najstarsze kościoły katolickie to kościół pw. Imienia Maryi (crkva Imena Marijina) i nieistniejący kościół św. Jana Nepomucena nad Dunajem, w tzw. kompleksie Mostobranu.

18 Ibidem, s. 34.

${ }^{19} \mathrm{~W}$ oficjalnym dokumencie wymieniono nazwę miasta w językach łacińskim, niemieckim $\mathrm{i}$ węgierskim, ale wkrótce pojawiła się także nazwa serbska - Novi Sad; ibidem, s. 34.

20 Уметничка топографија Новог Сада, red. Д. Станчић, Нови Сад 2014, s. 75. 


\section{SERBOWIE}

Od XV do XIX wieku na ziemie na północ od Sawy i Dunaju przesiedliło się kilkaset tysięcy Serbów, część zamieszkała na terenie dzisiejszych Węgier ${ }^{21}$, część zaś w Sremie, Baczce i Banacie ${ }^{22}$. Serbowie od samego początku byli także najliczniejszym narodem w zamieszkującym Petrovaradinski Šanec - najpierw jako budowniczowie Mostobranu, a potem osadnicy we wschodnich częściach miasta (najstarsze dzielnice to Almaški kraj, obecnie część dzielnicy Podbara, a także Salajka i Rotkvarija). Tutaj się osiedlali i zakładali pracownie rzemieślnicze, sklepy i karczmy. Tutaj powstało także istniejące do dziś przy ulicy Nikoli Pašića centrum duchowo-narodowe: barokowa cerkiew katedralna św. Jerzego (1734) i stojący obok dwór biskupi, jedna z ikon architektonicznych Nowego $\mathrm{Sadu}^{23}$. Tuż obok znajduje się Platoneum, fundacja biskupa Platona Atanackovicia ${ }^{24}$, w którym od XIX wieku mieściły się kolejno siedziba biskupstwa, Macierz Serbska, gimnazjum, wydział filozoficzny miejscowego uniwersytetu, a obecnie oddział Serbskiej Akademii Nauk i Sztuk. Za budynkiem znajduje się monumentalne Gimnazjum im. Jovana Jovanovicia Zmaja (1900). Zwieńczeniem ulicy jest monumentalny budynek fundacji Marii Trandafil z lat 1910$1912^{25}$, który od 1928 roku jest siedzibą Macierzy Serbskiej i Biblioteki Macierzy Serbskiej. To najstarsza i jedna z najważniejszych serbskich instytucji naukowo-kulturalnych, w 1826 roku założona w Budapeszcie, a w 1864 roku przeniesiona do Nowego Sadu.

Niechlubny niestety przykład braku dbałości o własną spuściznę stanowi grupa krytych strzechą domków typu wiejskiego (trščare), najstarszych w mieście, bo pochodzących z początków osadnictwa w mieście ${ }^{26}$. Przez niedbałość właścicieli i brak zainteresowania ze strony miasta, objęte w 1989 roku opieką konserwatorską budynki popadły w ruinę, a gdy kilka lat temu usunięto je ze spisu zabytków, teren kupił deweloper i rozpoczął ich wyburzanie pod budowę bloków mieszkalnych. Ofiarą zaniedbania padł w 1930 roku także ostatni zabytek turecki w mieście - Turska kuća ${ }^{27}$.

${ }^{21}$ W XVIII i XIX wieku do najważniejszych ośrodków kulturalnych i rzemieślniczych Serbów na Węgrzech należały Szentendre, Peszt, Györ i Komarno.

${ }^{22}$ Serbowie z Serbii centralnej i południowej, a także Raški i Kosowa migrowali na tereny Niziny Panońskiej od XV w.. Największe migracje nastąpiły na przełomie XVII i XVIII wieku. W trakcie Wielkiej Wędrówki Serbów (Velika seoba Srba), w 1690 r., wyemigrowało według różnych źródeł do 40 tysięcy rodzin. Kilkutysięczna migracja jest utożsamiana z wojną austriacko-turecką (1737-1739); Љ. Церовић, op. cit., s. 109-118.

${ }^{23}$ Istniejąca obecnie cerkiew św. Jerzego była kilkakrotnie przebudowana, po zbombardowaniu miasta w 1849 i w 1905 roku, gdy uzyskała obecny wygląd. Autorem projektu Dworu Biskupiego, który został zbudowany w 1901 r., był Vladimir Nikolić, który zaprojektował także Gimnazjum J. J. Zmaja i najważniejsze kościelne budynki w Sremskich Karłowicach (dwór patriarszy, seminarium duchowne, budynek Stefaneuт); Име и презиме, ор. cit., s. 130.

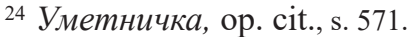

${ }^{25}$ Име и презиме, ор. cit., s. 254.

${ }^{26}$ Ibidem, s. 115.

${ }^{27}$ Ibidem, s. 113. 
Katolicy (Niemcy, Węgrzy, Szokcy i Buniewcy), a potem także Żydzi, zamieszkiwali przede wszystkim zachodnią część miasta. Najciekawsze zabytki związane z kulturą niemiecką, węgierską i żydowską znajdują się na zachód od placu Wolności.

\section{NIEMCY}

W podróż statkiem z portu w Ulm (rzadziej z Regensburga), przez Wiedeń, do swej nowej ojczyzny od początku XVIII wieku wyruszali Niemcy głównie z południowozachodnich części Niemiec. ze Szwabii, Saksonii, Badenii, Wirtembergii, Bawarii. Na początku XX wieku nazwano ich Donauschwaben, Podunavske Švabe. Na nowe ziemie Niemcy, zgodnie z planami Habsburgów, przynosili wiedzę i doświadczenie w dziedzinie rolnictwa i metod uprawy ziemi (np. trójpolówka, nawożenie), uprawy winorośli i tytoniu, a także nowoczesnych technik rzemieślniczych. Przynieśli także mentalność: kult pracy, kulturę mieszkania. Choć sami dostosowali się do nowego, wielokulturowego otoczenia, stali się także motorem rozwoju ekonomicznego i modernizacji, a także wzorem dla innych wspólnot.

Nemački kolonista se prilagodio svojoj etnički, konfesionalno i kulturno raznolikoj sredini, ali nije samo postao deo nje, već je i učestvovao u njenom oblikovanju, i to sa dugoročnim posledicama. U područje privrede, kao što smo videli, modernizacijom poljoprivrede, čiji je bio nosilac, u kulturnom smislu, zahvaljujući uzajamnim uticajima, koji su trajno promenili kako materijalnu, tako i duhovnu kulturu njegove seoske zajednice i okruženja ${ }^{28}$.

W Wojwodinie Niemców osiedlano najpierw w Banacie ${ }^{29}$, a potem także w Baczce i Sremie. Rzemieślnicy i kupcy zainteresowani byli raczej miastami, więc już pod koniec XVII wieku pierwsi Niemcy pojawili się w pobliżu garnizonu wojskowego w Petrovaradinskim Šancu. W 1739 roku dołączyła do nich kolejna grupa Niemców, tym razem z Belgradu, którzy wraz z kupcami serbskimi stali się inicjatorami libertacji. Niemcy do Nowego Sadu przybywali nieprzerwanie aż do I wojny światowej. W okresie międzywojennym oraz w czasie II wojny światowej stanowili znaczną, kilkunastoprocentową, część mieszkańców miasta ${ }^{30}$. Pod koniec II wojny światowej większość Niemców uciekła z Wojwodiny, a pozostali, w ramach odpowiedzialności zbiorowej za kolaborację $\mathrm{z}$ hitlerowskim okupantem ${ }^{31}$, poddani zostali represjom -

${ }^{28}$ G. Seewann, op. cit., s. 27.

${ }^{29}$ Panem Banatu i głównym administratorem dbającym o zasiedlanie tego terenu w pierwszej połowie XVIII wieku był austriacki namiestnik, hrabia Claudius Florimund de Mercy. Љ. Церовић, op. cit., s. 140.

30 Według danych szacunkowych, w międzywojniu około 50\% mieszkańców Nowego Sadu stanowili Serbowie, Węgrzy 20\%, Niemcy 12\% a Chorwaci 5\%; S. Bjelica, Politički razvoj Novog Sada između dva svetska rata, Novi Sad 2008, s. 107.

${ }^{31}$ Władze okupacyjne były aktywnie wspierane zwłaszcza przez niemieckich mieszkańców Banatu, który choć formalnie należał do Serbii reżimu Milana Nedicia, to w praktyce znajdował się pod ich pełną kontrolą i administracją. Pod koniec wojny, w obliczu zbliżających się oddziałów jugosłowiańskiej party- 
pozbawieni praw obywatelskich, skierowani do obozów pracy lub obozów koncentracyjnych. Od lat pięćdziesiątych większość z tych, którzy pozostali w Wojwodinie, dobrowolnie wyjechała do Austrii i Niemiec.

Choć Niemców już w Nowym Sadzie prawie nie ma, pozostała po nich potężna twierdza Petrovaradin (nazywana Gibraltarem nad Dunajem) ${ }^{32}$ oraz niewielka, murowana kolumna nad brzegiem rzeki, pozostałość po zburzonym w latach 30 . XX wieku Mostobranie oraz kościele Jana Nepomucena. Innym ciekawym zabytkiem łączącym Niemców i Węgrów jest niedawno odrestaurowany budynek strzelnicy Eđšeg $(\text { Egység })^{33}$, w którym elita miejska w XIX wieku organizowała bale i bankiety. Ostatnim wielkim dziełem i spuścizną Niemców jest modernistyczny budynek z 1931 roku (Habag), który był siedzibą Niemiecko-Szwabskiego Związku Kulturalnego (Kulturbund) oraz innych niemieckich organizacji kulturalnych i sportowych. Po wojnie budynek przejęły jugosłowiańskie, a obecnie użytkują serbskie koleje.

\section{WĘGRZY}

Masowa rekolonizacja Węgrów w Wojwodinie ${ }^{34}$ rozpoczęła się po likwidacji Nadcisańskiego Pogranicza Wojskowego (1751) i objęła głównie północną Baczkę (miasta Senta, Kanjiža, Subotica i Sombor).

W Petrovaradinskim Šancu Węgrzy obecni byli od końca XVII w., w 1748 spotykamy ich wśród grupy mieszczan starających się o status wolnego miasta. Najlepszym dla nich okresem okazał się jednak dopiero koniec XIX w., kiedy po porozumieniu z Habsburgami i ogłoszeniu dualnych Austro-Węgier (1867), rozpoczęła się państwowa madziaryzacja. Dzięki niej Węgrzy stali się najliczniejszą (lub jedną z najliczniejszych) grupą narodową w Nowym Sadzie ${ }^{35}$, rozwijali działalność kulturalną, wydawniczą, oświatową i organizacyjną. W 1889 roku na peryferiach miasta stworzyli nowe osiedle Telep, w którym osiedlano biedniejszych Węgrów z zadaniem odnowy uprawy winorośli.

Spośród obecnych na każdym kroku śladów obecności Węgrów wymienić należy katolickie zabytki sakralne (i nie tylko) autorstwa węgierskiego architekta György

zantki wspieranych przez Armię Czerwoną, większość z Niemców uciekła z Jugosławii. Pozostali zostali pozbawieni praw obywatelskich i poddani represjom.

32 Twierdza Petrovaradin była budowana w latach 1692-1780 według projektu Francuza Sebastiana Vobana; Име и презиме, ор. cit., s. 448.

${ }^{33}$ Budynek należący do najstarszego w Nowym Sadzie towarzystwa sportowego, Towarzystwa Strzeleckiego, powstał w latach 1889-1890 według projektu architekta György Molnára. Уметничка, s. 353 .

${ }^{34}$ Zamieszkująca w średniowieczu obszary dzisiejszej Wojwodiny ludność węgierka, po przegranej bitwie pod Mohaczem (1526) niemal w całości przesiedliła się na północ. Do Wojwodiny Węgrzy powracali od połowy XVIII wieku.

35 Przed wybuchem I wojny światowej Węgrów w Nowym Sadzie było około 11 tysięcy, Serbów 10 tysięcy, Niemców 6 tysięcy a Żydów blisko 2 300; Уметничка, op. cit., s. 80. 
(Đerđa) Molnára: zgłasza neogotycki kościół pod wezwaniem Imienia Maryi z końca XIX wieku (kiedyś istniał przy nim także budynek należący do katolickiej parafii) oraz usytuowany naprzeciwko Ratusz Miejski. Nieco dalej znajduje się kościół ewangelicko-reformowany (kalwiński) z lat 1862-1865, z wieżą zwieńczoną gwiazdą betlejemską. Przy ulicy Futoškiej usytuowano secesyjne budynek gimnazjum węgierskiego, a naprzeciwko - koszary honwedów ${ }^{36}$.

\section{SŁOWACY I RUSINI}

Od połowy XVIII wieku w Wojwodinie byli osadzani niemal równocześnie, Słowacy i Rusini. Pierwsze grupy Słowaków osiedlały się w Bačkim Petrovacu (1745), a następne w pobliskich miejscowościach (Stara Pazova, Kać, Kulpin). Pod koniec XVIII wieku dotarli oni do Nowego Sadu, ich życie społeczne skupiało się wokół miejscowej słowacko-niemieckiej parafii ewangelickiej. W 1886 roku wspólnie z Niemcami wybudowali kościół ewangelicki ${ }^{37}$. Obok znajduje się dziś Towarzystwo Kulturalne im. Pavla J. Šafarika, a także dawna siedziba niemieckiej ewangelickiej gminy wyznaniowej. Ten ostatni budynek jest siedzibą węgierskojęzycznego Teatru Nowosadzkiego (Újvideki Szinház).

Rusini przybyli w połowie XVIII wieku z terenów dzisiejszej Słowacji północno-wschodniej, najpierw do Ruskiego Krstura, następnie do Kucury, a stamtąd w 1766 roku do Nowego Sadu ${ }^{38}$. W 1780 roku założyli tam parafię greckokatolicką, która w 1838 roku wzniosła cerkiew św: Piotra i Pawła ${ }^{39}$. Obok niej działa obecnie Rusińskie Centrum Kultury.

\section{ŻYDZI}

Żydzi do Wojwodiny przybywali najczęściej z północy (Aszkenazyjczycy z ziem polskich, Moraw i Węgier), rzadziej z południa (Sefardyjczycy z Belgradu w latach 1738-1739). Początkowo mogli osiedlać się wyłącznie w miastach Baczki (Nowy Sad, Sombor, Subotica), w Banacie i Sremie stało się to możliwe dopiero pod koniec XIX wieku.

Pierwsi Żydzi na terenie Nowego Sadu osiedlili się w 1693 r., w 1717 roku w mieście istniała już synagoga z rabinem. Po 1748 roku wszystkich mieszkańców żydowskiego pochodzenia przesiedlono w okolice dzisiejszej ulicy Jevrejskiej, gdzie stwo-

36 Kościół pw. Imienia Maryi został zbudowany w latach 1892-1895, a ratusz w 1893-1895. Budynki te, jak i wiele innych (Eđšeg, kościół kalwiński) były projektowane przez architekta György Molnára; Име и презиме, op. cit., s. 122, 132-133.

37 Име и презиме, ор. cit., s. 145-146.

38 Я. Рамач, Руснации у Южней Угорскей (1745-1918), Нови Сад 2007, s. 103, 126.

${ }^{39}$ Име и презиме, ор. cit., s. 147-148. 
rzono żydowską dzielnicę - getto. Wybudowano tutaj nową synagogę, szkołę i szpital, a wzdłuż ulicy rozwinęły się sklepy i pracownie rzemieślnicze, istniejące aż do czasu II wojny światowej. Po tragicznych wydarzeniach wojennych, większość dawnych żydowskich mieszkańców nie wróciła do miasta. W latach 70., w celu poszerzenia istniejącej ówczesnej alei Josipa Broza Tity, a także stworzenia miejsca pod budowę nowej siedziby Serbskiego Teatru Narodowego, zburzono część historycznej ulicy Jevrejskiej.

Najwspanialszym zabytkiem żydowskim i jednocześnie najbardziej monumentalnym obiektem sakralnym w Nowym Sadzie jest secesyjna synagoga z lat 19061909, wzniesiona według projektu budapeszteńskiego architekta Lipóta Baumhorna. Stanowiła ona część kompleksu wraz ze szkołą i siedzibą żydowskiej gminy wyznaniowej.

\section{CINCARZY, GRECY, ORMIANIE}

Od końca XVII wieku w Nowym Sadzie osiedlali się Cincarzy, Grecy i Ormianie, określano także jako „tureccy kupcy”, pośrednicy w handlu oraz kulturze między chrześcijańską Europą a Turcją osmańską.

Cincari, nazywani także miejskimi Wołochami (Arumuni), w XVIII wieku byli silnie zhellenizowani, z tego względu w źródłach często wymienia się ich razem z Grekami. W Wojwodinie pojawili się oni pod koniec XVII w., podczas tzw. Wielkiej Wędrówki Serbów, a następnie w wyniku ucieczki z Belgradu (1738-1739). Po 1769 roku dotarli imigranci ze spalonego Moskopola - ważnego ośrodka kultury i handlu. Cincarzy tworzyli elitę mieszczańską, rozwijali handel ze Wschodem, dbali o oświatę, kulturę i szerzenie idei oświeceniowych. Uchodzili za hojnych filantropami. W miastach zakładali szkoły, tak jak na przykład w 1783 roku w Nowym Sadzie, gdzie działała ona do lat sześćdziesiątych XIX wieku. Wówczas budynek szkolny został przekazany na potrzeby serbskiego gimnazjum, czego świadectwem jest tablica pamiątkowa w języku greckim, umieszczona na murze zaniedbanego obecnie gmachu przy ulicy Grčkoškolska. Cincarskiego pochodzenia były wpływowe rodziny z Nowego Sadu, wśród nich należy wymienić choćby ród Trandafilów. Dzięki wsparciu Marii Trandafil i stworzonego przez nią funduszu dobroczynnego, po 1851 roku wyremontowano cerkiew św. Mikołaja ${ }^{40}$, a na początku XX wieku zbudowano obecną siedzibę Macierzy Serbskiej.

Ormianie osiedlili się w Nowym Sadzie po 1739 r.. W 1746 roku licząca około setki osób wspólnota wybudowała własną świątynię, należąca do ormiańsko-katolickiej kongregacji mechiarystów. Zburzony w 1849 roku kościół, został odbudowany dzięki pomocy Marii Trandafil w 1891 roku, do połowy XX wieku był on pięknym świadectwem obecności Ormian w mieście. W 1951 roku został wpisany na listę za-

\footnotetext{
${ }^{40} \mathrm{Na}$ murach cerkwi cerkwi św. Mikołaja odkryto napis po grecku, świadczący, że została ona wzniesiona w 1733 roku, por. Уметничка, op. cit., s. 555.
} 
bytków kultury, co nie uchroniło go przed najgorszym. Budynek zburzono w 1963 roku w związku z rozbudową alei Josipa Broza Tity ${ }^{41}$. Wydarzenie to, a także zmiana nazwy placu Ormiańskiego na plac Galerii, spowodowały powolne wymazywanie ormiańskich śladów ze współczesnego życia miasta. Kolejnym etapem tego procesu była budowa biurowca na miejscu dawnego kościoła i cmentarza. Usunięto wówczas pomnik nagrobny rodziny Czenazi i mozaikę chodnikową, która odwzorowywała zarys murów nieistniejącej świątyni. Pozostał jedynie chaczkar - współczesny pomnik przyjaźni serbsko-ormiańskiej.

Po dramatycznym w skutkach bombardowaniu miasta w 1849 roku przez oddziały węgierskie, gdy spośród prawie trzech tysięcy budynków zachowało się zaledwie kilkaset, Nowy Sad odrodził się jako centrum życia kulturalnego, społecznego i politycznego Serbów. Od lat sześćdziesiątych do połowy lat siedemdziesiątych XIX wieku nastąpił tam gwałtowny rozwój serbskiej kultury. Utworzono serbską czytelnię (1845), teatr narodowy $(1861)^{42}$, z Budapesztu sprowadzono Macierz Serbską (1864). W mieście kształtowała się nowoczesna młoda elita serbska, działali pisarze i poeci, dyskutowali młodzi politycy ${ }^{43}$. Dzięki nim Nowy Sad zyskał przydomek Serbskich Aten. Choć to obiektywnie skromny rozwój, to w skali serbskiej kultury oznaczał on przełom w historii kulturalnej i politycznej Serbów. Od lat siedemdziesiątych XIX wieku był on kontynuowany w stołecznym Belgradzie, który stał się centralnym ośrodkiem serbskiej inteligencji.

Równocześnie rozwijało się życie kulturalne innych narodów, wydawano gazety, prowadzono szkoły niemieckie, węgierskie i żydowskie. Po utworzeniu dualistycznej monarchii Austro-Węgier, nastąpiła powolna, państwowa madziaryzacji Wojwodiny, która doprowadziła do wzrostu liczby Węgrów w Nowym Sadzie i wkrótce stali się oni dominującym w mieście narodem.

\section{KOLONIZACJE POWOJENNE W XX WIEKU}

Po I wojnie światowej, w nowych okolicznościach politycznych i po stworzeniu zjednoczonego państwa Słowian południowych, kolejny raz zmieniła się struktura etniczna Wojwodiny. Powojenną zmianę geopolityczną szczególnie odczuli Węgrzy i Niemcy. Po raz pierwszy ich centra polityczne i kulturalne znalazły się poza granicami Węgier, a oni sami stali się narodami mniejszościowymi. Wojwodińscy Serbowie

${ }^{41} \mathrm{~W}$ czasie rozbudowy miasta w latach 60 . XX wieku, zdecydowano o alei, która obecnie nosi imię Mihajla Pupina. Kościół ormiański zburzono, choć zasadniczo nie przeszkadzał on w budowie nowej trasy.

${ }^{42}$ Serbski Teatr Narodowy w Nowym Sadzie jest najstarszym profesjonalnym teatrem w Serbii.

${ }^{43}$ Spośród największych postaci życia publicznego miasta w drugiej połowie XIX wieku wymienić należy Jovana Jovanovicia Zmaja, Lazę Kosticia, Đurę Jakšicia, pisarzy Milovana Vidakovicia, Jakova Ignjatovicia i polityków Svetozara Mileticia, Mihajla Polita Desančicia, Svetozara Markovicia, Jašę Tomicia. 
znaleźli się w swoim własnym państwie, którego władza, oprócz innych reform, prowadziła działania zmierzające do homogenizacji narodowej i wzmocnienia czynnika słowiańskiego w tej byłej węgierskiej prowincji. Jak pisała badaczka dziejów nowosadzkiego rzemiosła Donka Stančić:

Država je nizom političkih, privrednih i prosvetnih mera pokušavala da ostvari bar minimum homogenosti a u nacionalno mešovitoj Vojvodini te su mere bile u službi jačanja srpskog i slovenskog stanovništva za račun nemačkog i mađarskog. Oslanjajući se na iskustva iz Mađarske, srpski prečanski javni radnici smatrali su da je u tom procesu 'slovenizacija gradova'od prvorazrednog značaja ${ }^{44}$.

Chcąc zmienić strukturę narodowościową i zniwelować skutki wcześniejszej madziaryzacji, przeprowadzano akcję osiedlania Serbów z południa Serbii, Kosowa, Bośni i Liki. Z drugiej zaś strony około 45 tysięcy Węgrów wyjechało wtedy z Królestwa SHS. Struktura etniczna Wojwodiny zmieniła się tym razem na korzyść Serbów, liczba ludności Nowego Sadu wzrosła z 39 tysięcy w 1921 roku do blisko 70 tysięcy zaraz przed wybuchem II wojny światowej, głównie dzięki przybyszom z południa (w 1929 roku zaledwie 38,4\% mieszkańców było urodzonych w Nowym Sadzie) ${ }^{45}$.

Miasto, od 1929 roku stolica Banoviny Dunajskiej, ciągle się rozwijało, budowano nowe dzielnice, osiedlali się nowi mieszkańcy. W latach 1919-1924 do Wojwodiny przybyło około 8 tysięcy osób, uciekinierów z Rosji, pogrążonej w wojnie domowej (tzw. Biali Rosjanie). W Sremskich Karłowicach (Sremski Karlovci) zorganizowany został tzw. Rosyjski Sztab Główny wraz z Synodem Rosyjskie Cerkwi za Granicą. Około 2 tysięcy osób rosyjskiego pochodzenia trafiło do Nowego Sadu, gdzie dzięki swemu wykształceniu widoczni byli w życiu naukowym, oświatowym i kulturalnym. Śladem ich obecności jest zbudowany w latach 20. XX wieku nad Dunajem Dom Oficerski, w stylu reprezentacyjnego rosyjskiego klasycyzmu.

W okresie międzywojennym w mieście działały liczne organizacje społecznokulturalne, polityczne i sportowe, zarówno serbskie, jak i najważniejszych mniejszości. Od 1920 roku główną organizacją kulturalno-oświatową, a w latach 30. także polityczną, trzeciej pod względem liczebności mniejszości był Niemiecko-Szwabski Związek Kulturalny (Kulturbund), który dbając o język i kulturę, wielu Niemcom pomógł odkryć swoją tożsamość ${ }^{46}$. Mniejszość węgierska działała najpierw wokół Węgierskiego Kręgu Katolickiego, a potem Związku Węgierskich Stowarzyszeń Kulturalnych. W przeddzień wybuchu II wojny organizacje reprezentujące Węgrów i Niemców działały w interesie państw macierzystych - Węgier i Rzeszy Niemieckiej. Ich ówczesna aktywność przyniosła dalekosiężne skutki w powojennych losach obu wspólnot narodowych.

44 Уметничка, ор. cit., s. 84.

45 S. Bjelica, op. cit., s. 107.

46 Pod wpływem przedstawicieli młodego pokolenia Niemców, z których część kończyła studia w Niemczech i Austrii, w latach trzydziestych XX wieku organizacja niemieckiej mniejszości radykalizowała się, przejmując ideologię nazistowską. 
Okres II wojny światowej i węgierska okupacja Baczki spowodowały zmiany w strukturze narodowościowej miasta. Na początku węgierskiej okupacji, z Nowego Sadu do Serbii wysiedlono 15 tysięcy osób, które się w nim osiedliły w okresie międzywojennym ${ }^{47}$. W wyniku egzekucji, deportacji do obozów zagłady, a także Pogromu Nowosadzkiego ze stycznia 1942 r., z miasta zniknęli niemal wszyscy jego żydowscy mieszkańcy. W obliczu nadciągających wojsk partyzanckich wspomaganych przez Armię Czerwoną, w 1944 roku z Baczki uciekło około 40 tysięcy Węgrów, a ci, którzy pozostali, padli ofiarą represji z rąk komunistów ${ }^{48}$. Także większość (około 200 tysięcy) spośród około 340 tysięcy wojwodińskich Szwabów uciekła do Niemiec i Austrii. Wobec Niemców, którzy pozostali, stosowano metody odpowiedzialności zbiorowej, poddawano ich represjom i samosądom, rozstrzeliwano, wywożono do obozów pracy w ZSRR, a także gromadzono w obozach koncentracyjnych i pracy. Jak podają D. Boarow i Z. Janjetović, w latach 1944-1948 z głodu, chorób lub wycieńczenia, w jugosłowiańskich obozach dla Niemców zmarło około 50 tysięcy osób ${ }^{49}$. Większość z pozostałych przy życiu, w latach powojennych wyjechała z Jugosławii ${ }^{50}$.

Po raz kolejny to zwycięzcy ustalali zasady życia w mieście. I po raz kolejny w Wojwodinie wprowadzono je poprzez wymianę ludności i kolonizację. Akcja osadnicza w latach 1944-1948 objęła blisko 250 tysięcy przybyszów z Serbii centralnej, Czarnogóry, Bośni i Hercegowiny, Macedonii, Chorwacji oraz Słowenii.

W powojennej Jugosławii Nowy Sad stał się centrum administracyjnym i politycznym okręgu autonomicznego Wojwodina, gdzie swoje siedziby miały także organizacje mniejszościowe i media państwowe, emitujące program telewizyjno-radiowy oraz wydające prasę w językach mniejszości. W atmosferze dość tolerancyjnej polityki władz, zwłaszcza od połowy lat 70 . XX wieku ${ }^{51}$, na miejscowym uniwersytecie istniały katedry języków i literatur najważniejszych mniejszości - węgierskiej, słowackiej, rumuńskiej oraz rusińskiej.

Kolejny rozdział w historii migracyjnej Nowego Sadu stanowiły lata 90. XX wie$\mathrm{ku}$, gdy doszło do rozpadu socjalistycznej Jugosławii i wybuchu działań wojennych w Chorwacji, Bośni i Hercegowinie oraz Kosowie. Do miasta przybyło wówczas blisko 50 tysięcy uchodźców ${ }^{52}$, z których większość pozostała na stałe. W tym samym czasie Wojwodinę opuściły setki Węgrów i Chorwatów, bezpośrednio lub pośrednio

${ }^{47} \mathrm{Z}$ terenu Baczki wysiedlono od 20 tysięcy do 30 tysięcy Serbów; D. Boarov, op. cit., s. 166.

48 Dimitrije Boarov, op. cit., s. 183.

${ }^{49}$ Ibidem, s. 182; Zavičaj na Dunavu, op. cit. 222.

${ }^{50} \mathrm{~W} 1947$ roku w Wojwodinie odnotowano pozostało 111740 Niemców, w latach 50. liczba ta zmniejszyła się do około 50 tysięcy. Według ostatniego spisu ludności, w Wojwodinie mieszka około 4 tysięcy osób, które uznają się za Niemców; Zavičaj na Dunavu, op. cit., s. 72.

${ }^{51}$ Zgodnie z zapisami konstytucji socjalistycznej Jugosławii z 1974 r., Federacyjny Autonomiczny Okręg Wojwodiny był konstytutywną częścią federacji z szeroką autonomią w każdej dziedzinie życia publicznego. W praktyce posiadał niemal wszystkie cechy republiki związkowej.

52 Według części historyków, duże migracja ludności do Wojwodiny w latach 90. XX wieku była związana z politykę ówczesnych władz jugosłowiańskich. Ich celem była zmiana proporcji 
zmuszanych do emigracji. Od początku lat 90., z Wojwodiny, a także z całej Serbii, emigrowali młodzi, często wykształceni Serbowie, głównie z powodów ekonomicznych.

W wyniku dynamicznych ruchów migracyjnych, na progu XXI wieku w około 250-tysięcznym Nowym Sadzie mieszkało około 197 tysięcy Serbów (78,68\%), blisko 10 tysięcy Węgrów (3,88\%), ponad 3 tysiące Chorwatów 3.295 (1,31\%), 3 tysiące Romów $(1,26 \%)$ oraz Czarnogórców $(1,23 \%)$. Około 2 tysiące mieszkańców miasta $(1,19 \%)$ deklarowało się jako Jugosłowianie. Poza tym w Nowym Sadzie odnotowano mieszkających tam Słowaków (1780 osób, 0,71\%), Rusinów (1721 osób, 0,68\%), Macedończyków (892 osób), Muzułmanów (870 osób), Rumunów (772 osób), Gorańców (568 osób), Niemców (348 osób), Słoweńców (335 osób), Ukraińców (301 osób), Albańczyków (291 osób), Rosjan (267 osób), Bunjevcow (242 osoby), Bošnjaków (126 osób), Bułgarów (121 osób) ${ }^{53}$. O tym ostatnim okresie w historii współczesnej Nowego Sadu napisał László Végel, pochodzący z Srbobranu węgierski pisarz i publicysta:

Nekadašnja demografska slika se iz osnova promenila. Nemci su proterani 1945. ili su se iselili usled represalija, broj Jevreja je danas skoro zanemarljiv, broj Mađara je pao ispod 5\%, tako da je njihovo kulturno prisustvo od devedesetih godina još samo simbolično, marginalno. Ono što je šezdesetih, sedamdesetih godina (XX veka) bilo karakteristično ne samo za bivšu Jugoslaviju, već i za Novi Sad sa celim regionom, se svake godine sve više $i$ više gubi. Danas se u svakom slučaju može još govoriti o perifernim kulturama na rubu nacionalnih država ${ }^{54}$.

Nowy Sad był i jest miastem tworzonym przez różne narody i kultury, których udział zmieniał się w czasie jego ponad trzystuletniej historii. Najczęściej do zmian dochodziło w wyniku działań politycznych suwerenów, osiedlających bądź, rzadziej, wypędzających określone grupy etniczne. To zwycięzca decydował o tym kogo zaprosić, a kogo wyprosić. Na szczęście nie zmieniło to w sposób znaczny wielokulturowego charakteru miasta, choć znaczenie lub obecność kilku ważnych narodów, którzy w kulturze, przestrzeni miejskiej i ludzkiej świadomości pozostawili ślad po sobie, znacznie się zmniejszyły.

Nie zawsze udawało się zadbać o wszystkie te namacalne ślady kulturowe w mieście, czego ofiarami stały się turska kuća na Podbarze, kultowe XIX-wieczne kafany w centrum, prawosławna cerkiew św. Jana (Svetojovanovska), kościół Jana Nepomucena i Mostobran nad Dunajem, kościół ormiański czy cały kwartał śródmiejski wyburzony pod budowę nowej, przeskalowanej siedziby Serbskiego Teatru Narodowego. Nowszymi przykładami co najmniej niedbałości jest zmiana charakte-

narodowościowych w regionie na korzyść Serbów; por. Helsinški odbor za ljudska prava u Srbiji, U potrazi za građanskim identitetom, Beograd 2004.

${ }^{53}$ Dane spisu powszechnego z 2011 roku: Попис становничитва, домаћинстава и станова 2011. y Републици Србији. Национална припадност. Подаии по опитинама и градовима, Београд 2012, http://pod2.stat.gov.rs/ObjavljenePublikacije/Popis2011/Nacionalna\%20pripadnost-Ethnicity.pdf [dostęp: 13.09.2017].

${ }^{54}$ Zavičaj na Dunavu, op. cit., s. 106. 
ru niskiej zabudowy centrum miasta, burzenie zabytkowych domków trščare czy podejmowane przez prywatnego dewelopera działania wokół dawnego kościoła ormiańskiego.

Dawniej była to niedbałość, ignorancja lub ideologia, poświęcająca ,ślady starych czasów” dla budowy „nowego i lepszego porządku”. Dzisiaj coraz częściej ignorancji towarzyszy chęć zysku i brak myślenia perspektywicznego. Oczywista jest presja związana z rozwojem miasta, ciągłym napływem ludności z okolic, ale takie zmiany nie muszą przecież dokonywać się kosztem zabytków. Na włodarzach miasta stoi tym bardziej ważne zadanie, że w 2016 roku Nowemu Sadowi został przyznany tytuł Europejskiej Stolicy Kultury $2021^{55}$. Może to zmieni myślenie i pozwoli zadbać o pamięć i zabytki.

Drugą istotną sprawą, na którą zwraca uwagę część obserwatorów wojwodińskiej rzeczywistości, jest odpowiednie podejście do tradycji miasta przez władze samorządowe. Te często powołują się na tradycję Serbskich Aten, podkreślając szczególną rolę miasta w kulturze Serbów. Odbywa się to kosztem tradycji wielokulturowości, która zbudowała i przez wieki kształtowała oblicze Nowego Sadu. Należy mieć nadzieję, że hasło o budowaniu mostów ${ }^{56}$, dzięki któremu miasto zdobyło tytuł Europejskiej Stolicy Kultury, będzie oznaczać także pamięć o wszystkich kulturach, językach, narodach u religiach, które stworzyły jego wyjątkowy charakter.

\section{BIBLIOGRAFIA}

Bjelica Slobodan, Politički razvoj Novog Sada između dva svetska rata, Novi Sad 2008.

Boarov Dimitrije, Politička istorija Vojvodine: u trideset tri priloga, Novi Sad 2001.

Džepina Mirjana, Društveni i zabavni život starih Novosađana, Novi Sad 1982.

Farkaš Vena, Pored mosta Nada, izgrađen još jedan - komunikacija!, „Kulttura” 2007, nr 4, s. 15. Janjetović Zoran, Švabe u Vojvodini, w: Скривене мањине на Балкану, уред. Биљана Сикимић, Београд 2004.

Helsinški odbor za ljudska prava u Srbiji, U potrazi za građanskim identitetom, Beograd 2004.

Korzeniewska-Wiszniewska Mirella, Serbskie aspiracje do struktur europejskich. Sytuacja mniejszości narodowych $i$ etnicznych $w$ Autonomicznej Prowincji Wojwodiny ze szczególnym uwzględnieniem systemu kształcenia, „Slavia Meridionalis” 2012, t. 12, s. 187-201.

55 Jednym z głównych elementów programu Europejskiej Stolicy Kultury Novi Sad 2021 jest rewitalizacja położonego nad Dunajem, poprzemysłowego kwartału po dawnej fabryce Petar Drapšin (Kineska četvrt), przekształcenie go w ośrodek kultury i nowych technologii. plan rewitalizacji opracowano na podstawie konsultacji społecznych, które prowadzono w ramach kampanii „Divan”. Jednym z założeń jest wspieranie miejscowych rzemieślników i wprowadzenie ograniczeń dla lokowania w tym miejscu przedsięwzięć o charakterze komercyjnym; Saša Lekić, Utisci sa prvog „Divana”, „Kulttura” 2007, nr 3, s. 5; Vena Farkaš, Pored mosta Nada, izgrađen još jedan - komunikacija!, „Kulttura” 2007, 4, s. 15.

${ }^{56}$ Projekt Europejskiej Stolicy Kultury w Nowym Sadzie, o nazwie Dla nowych mostów, opiera się na czterech filarach (mostach): Sloboda - kreatywność i działalność młodych; Nada- potencjał kulturalny i przestrzeń publiczna; Novi - dziedzictwo kulturowe i gościnność; Duga - konflikty i migracje. Więcej: www.novisad2021.rs [dostęp: 18.10.2017]. 
Kulturni i etnički identiteti u procesu globalizacije i regionalizacije Balkana $=$ Cultural and ethnic identities in the process of globalization and regionalization of the Balkans, red. Ljubiša Mitrović, Dragoljub Đorđević, Dragan Todorović, Niš 2002.

Kwoka Tomasz, Wojwodińscy Rusini - między emancypacja a asymilacja. Prawna i społeczno-kulturalna sytuacja mniejszości rusińskiej w Wojwodinie, w: Krakowsko-Wileńskie Studia Slawistyczne, Kraków 2011, t. 6, s. 269-306.

Lekić Saša, Utisci sa prvog „Divana”, „Kulttura” 2007, nr 3, s. 5.

Migracije u Podunavlju. Kolonizacija Nemaca u 18. veku i njene posledice, Novi Sad 2013.

Mutlietnički identitet Vojvodine; izazovi u 2007-2008, red. Pavel Domonji, „Helsinške sveske“ 2008, nr 27.

Seewann Gerhard, O istoriji „Švaba na Dunavu”, w: Migracije u Podunavlju. Kolonizacija Nemaca u 18. veku i njene posledice, Novi Sad 2013, s. 25.

U potrazi za građanskim identitetom, red. Seška Stanojlović, Beograd 2004

Zavičaj na Dunavu. Suživot Nemaca i Srba u Vojvodini, ured. Vladimir Mitrović, Novi Sad-Ulm 2009.

$* * *$

Војвођанском гражданству у сусрет. каталог изложбе, Нови Сад, 2007.

Гавриловић Славко, Студије из привредне и друштвене историје Војводине и Славоније од краја XVII до средине XIX века, Нови Сад 2009

Драганић Ифигенија, Долазак и настањивање Грка на територију данашње Војводине, w: Bојвођански простор у контексту европске историје. Зборник радова, red. Владан Гавриловић, Дејан Микавица, Тибор Пал, Нови Сад 2012, s.161-167.

Име и презиме: Нови Сад, Нови Сад 2010.

Милитар Трива, Нови Сад на раскрснищи минулог и садањег века. По изворима, забелешкама и сећању Трива Милитар, Нови Сад 2000.

Попис становниитва, домаћинстава и станова 2011. у Републици Србији Национална припадност. Подаци по опитинама и градовима, Београд 2012.

Положај националних мањина у Србији: зборник радова са научног скупа одржаног 24-26. новембра 2005, red. Војислав Становчић, Београд 2007.

Пушкар Војислав, Пушић Љубинко, Блашковић Ласло, Поповић Блажо, Ређеп Драшко, Нови Сад: приче варошких улица, Нови Сад 2008.

Рамач Янко, Руснаци у Южней Угорскей (1745-1918), Нови Сад 2007.

Русини $=$ Руснаци $=$ Ruthenians (1745-2005), red. Михайло Фејса, Нови Сад 2006. t. 1.

Русини = Руснаци = Ruthenians (1745-2005), red. Михайло Фејса, Нови Сад 2008, t. 2.

Стајић Васа, Грађа за културну историју Новог Сада, Нови Сад 1951.

Стајић Васа, Нови Сад, Нови Сад 2011.

Уметничка топографија Новог Сада, red. Донка Станчић, Нови Сад 2014.

Церовић Љубивоје, Народи на тлу Војводине. Од праисторије до до двадесетог века, Нови Сад 2015. 